\title{
Coordinacy of Lysosomal Enzyme Excretion in Human
}

\section{Urine}

\author{
Kenneth Paigen and Janice Peterson, Department of Molecular Biology, Roswell \\ Park Memorial Institute, Buffalo, New York 14263
}

A B S T R A C T Assay conditions have been developed for the determination of urinary $\beta$-glucuronidase, $\beta$-galactosidase, $\alpha$-galactosidase, and $\beta$-hexosaminidase using fluorometric substrates. The assay conditions for $\beta$-glucuronidase overcome interference by both low and high molecular weight inhibitors, a problem that has confused earlier studies of enzyme excretion.

The four lysosomal enzymes are excreted coordinately; although their absolute levels (in units per milligram of (reatinine) vary during the day and from one day to the next, the ratio of one enzyme to another remains relatively constant. The lack of correlation between plasma and urine enzyme levels, together with the high molecular weights of these enzymes, suggests that the urinary enzymes are not derived by glomerular filtration. The lack of coordinacy with lactate dehydrogenase suggests they are not derived from exfoliated cells. By analogy with experimental animals, they may be derived from lysosomes extruded into the lumen of the proximal tubule by epithelial cells.

There is considerable variation among a population of 125 healthy adult subjects for total enzyme excretion. Both total enzyme excretion and coordinacy ratios are log-normally distributed, suggesting that they are the resultants of many factors, each of which has a relative, or proportional, effect on enzyme excretion. About one-half the population variation resides in a process common to the excretion of all four enzymes (possibly the lysosome extrusion pathway), and about one-half resides in factors affecting each enzyme independently.

\section{INTRODUCTION}

The presence of a variety of lysosomal enzymes has been reported in human urine (1), including $\beta$ glucuronidase, $\alpha$-galactosidase, $\beta$-galactosidase, $\beta$ - $N$ acetylglucosaminidase, $\alpha$-mannosidase, $\alpha$-amylase, aryl sulfatase, and acid phosphatase. Among these,

Received for publication 31 May 1977 and in revised form 24 October 1.977. $\beta$-glucuronidase has been the most extensively studied (for review see Wakabayashi [2]). Changes in the urinary level of this enzyme have been reported in a variety of pathological states, including urinary tract infection (3-6), renal disease (7), transplantation rejection (8), protein-calorie malnutrition (9), epilepsy (10), and neoplasms of the bladder (11), testes (12), larynx (12), and breast (12). In addition, the enzyme normally rises during the third trimester of pregnancy (4).

The presence of urinary glucuronidase has been implicated as an etiologic factor in the development of bladder cancer by Boyland and co-workers (13). They have suggested that the first step in carcinogenesis by aromatic amines and nitroso compounds is their activation by hydroxylation in liver. Before leaving the liver, the hydroxylated derivatives are further converted to noncarcinogenic products by conjugation, primarily with glucuronic acid. When excreted into urine, these conjugates come in contact with urinary glucuronidase. The favorable $\mathrm{pH}$ and temperature of urine in the bladder facilitate enzymatic hydrolysis with the liberation of active carcinogen. Elevated levels of glucuronidase have been observed in the urine of bladder cancer patients (11-14), but it is uncertain whether this is a cause or consequence of the disease.

One way to resolve this dilemma is to ask whether individual variation in glucuronidase excretion among normal individuals is genetically determined, and if so, to inquire whether bladder cancer patients carry a genetic predisposition to high enzyme excretion. The genetic characteristics of bladder cancer patients can be deduced without complication by the disease itself by measuring enzyme excretion in their progeny. As a preliminary to such experiments, we have examined the excretion of $\beta$-glucuronidase (E.C. 3.2.1.31) and three additional lysosomal enzymes: $\alpha$-galactosidase (E.C. 3.2.1.22), $\beta$-galactosidase (E.C. 3.2.1.23), and $\beta$ - $N$-acetylglucosaminidase (E.C. 3.2.1.30). For this it was necessary to develop new assay procedures, particularly for $\beta$-glucuronidase. The assay of glucuronidase in urine is confounded by the presence 
of high as well as low molecular weight enzyme inhibitors. Fortunately, the recent work of Sakamoto et al. (15-18) has provided a solution to this problem. In retrospect, it is now apparent that much of the published literature on glucuronidase excretion is of uncertain validity.

The primary observation we have made is that the lysosomal hydrolases present in human urine undergo coordinate variation. Their levels fluctuate in parallel, so that the ratio of each enzyme to the others remains constant. The average output of each enzyme, and its proportion to the others, is a rather constant characteristic of normal individuals. Among the human population there is a considerable range in excretion patterns that, with certain exceptions, is unrelated to age or sex. The explanation of coordinacy probably lies in the source of excreted enzyme, which appears to be lysosomes that are extruded into the lumen of proximal convoluted tubules by kidney epithelial cells.

\section{METHODS}

Urine collection. Urine was collected either as daily samples taken at the first voiding on rising in the morning, or as total volumes over a 24- to 30-h period. Enzyme stability in the bladder before collection does not seem to be a problem, since no differences in enzyme excretion were found comparing short ( $2 \mathrm{~h}$ ) and long (overnight) urine collections. To inhibit subsequent bacterial growth, samples were made $1 \mathrm{mM}$ in sodium azide at the time of collection and then refrigerated. Samples were analyzed within a few days of collection. Samples refrigerated in the presence of azide showed little change in enzyme activity after 5 days and $65-85 \%$ survival of the four lysosomal enzymes after a month of storage. Glucuronidase was the most stable enzyme and $\alpha$-galactosidase the least. These results were fairly uniform from one individual to the next.

After removal of an aliquot of urine for creatinine determination, $3 \mathrm{ml}$ of each sample was prepared for enzyme assay by dialysis in the cold for a minimum of $4 \mathrm{~h}$, but usually overnight, against two changes of $0.03 \mathrm{M}$ citrate buffer, $\mathrm{pH} 6.0$, containing $0.1 \%$ Triton $\mathrm{X}-100$ and $0.1 \mathrm{M} \mathrm{NaCl}$. This step removes low molecular weight inhibitors and is especially important in the assay of glucuronidase and hexosaminidase.

Assays. Assays of the four hydrolases studied were based on the fluorometric measurement of 4-methylumbelliferone $(4 \mathrm{MU})^{1}$ liberated from the appropriate glycoside. An aliquot of dialyzed urine $(0.02 \mathrm{ml})$ was taken for assay of each enzyme.

$\beta$-Glucuronidase. The aliquot was incubated at $37^{\circ} \mathrm{C}$ for $2 \mathrm{~h}$ in a stoppered tube in a final volume of $0.1 \mathrm{ml}$ containing $0.1 \mathrm{M}$ acetate buffer, $\mathrm{pH} 4.6,0.1 \mathrm{M} \mathrm{Na}_{2} \mathrm{SO}_{4}, 0.1 \%$ Triton X-100, and $3 \mathrm{mM} 4 \mathrm{MU}$-glucuronide trihydrate. The reaction was stopped and the fluorescence developed by the addition of 1.3 $\mathrm{ml}$ of $0.1 \mathrm{M} \mathrm{Na}_{2} \mathrm{CO}_{3}$.

$\alpha$-Galactosidase. The aliquot was incubated at $37^{\circ} \mathrm{C}$ for $2 \mathrm{~h}$ in a stoppered tube in a final volume of $0.1 \mathrm{ml}$ containing 0.1 $\mathrm{M}$ citrate buffer, $\mathrm{pH} 4.9$, and $7 \mathrm{mM} 4 \mathrm{MU}-\alpha$-D-galactoside. The reaction was stopped and the fluorescence developed by the addition of $1.3 \mathrm{ml}$ of $0.1 \mathrm{M} \mathrm{Na}_{2} \mathrm{CO}_{3}$.

$\beta$-Galactosidase. Because of the limited solubility of the

${ }^{1}$ Abbreviations used in this paper: 4MU, 4-methylumbelliferone; NAD, nicotinamide adenine dinucleotide. $\beta$-galactosidase substrate, the concentration used in the standard assay procedure was below that required to saturate the enzyme. The aliquot was incubated at $37^{\circ} \mathrm{C}$ for $1 \mathrm{~h}$ in a stoppered tube in a final volume of $0.3 \mathrm{ml}$ containing $0.1 \mathrm{M}$ citrate buffer, $\mathrm{pH} 4.9,0.1 \mathrm{M} \mathrm{NaCl}$, and $0.25 \mathrm{mM} 4 \mathrm{MU}-\beta$-Dgalactoside. The reaction was stopped and the fluorescence developed by the addition of $1.3 \mathrm{ml}$ of $0.3 \mathrm{M} \mathrm{Na}_{2} \mathrm{CO}_{3}$.

Hexosaminidase. The aliquot was incubated at $37^{\circ} \mathrm{C}$ for $0.5 \mathrm{~h}$ in a stoppered tube in a final volume of $0.1 \mathrm{ml}$ containing $0.1 \mathrm{M}$ citrate buffer, $\mathrm{pH} 4.9,0.1 \mathrm{M} \mathrm{NaCl}$, and $3 \mathrm{mM}$ $4 \mathrm{MU}-2$-acetamido- 2 deoxy- $\beta$-D-glucoside. The reaction was stopped and the fluorescence developed by the addition of 1.3 $\mathrm{ml}$ of $0.1 \mathrm{M} \mathrm{Na}_{2} \mathrm{CO}_{3}$.

Under these reaction conditions, $4 \mathrm{MU}$ release was proportional to enzyme concentration and time for each of the enzyme assays. Fluorescence was measured in an Aminco (American Instrument Co., Silver Spring, Md.) fluorocolorimeter equipped with interference filters for excitation at $371 \mathrm{nM}$ and emission at $456 \mathrm{nM}$. (As an alternative, one can use a Corning 7-60 filter for excitation and a Kodak 2A filter for emission.) Included in each batch of assays were a $4 \mathrm{MU}$ standard $(1 \mathrm{nmol})$ and an enzyme standard. For the latter purpose we have used a $10 \%$ homogenate of mouse liver prepared in $0.25 \mathrm{M}$ sucrose containing $0.02 \mathrm{M}$ imidazole buffer, pH 7.4. This is stable indefinitely when frozen. A $0.02-\mathrm{ml}$ aliquot of $1 / 10-1 / 40$ dilution of the homogenate provided an adequate standard. Enzyme activities are expressed as nanomoles of product formed per hour per milligram of creatinine.

The enzyme substrates $4 \mathrm{MU}$-glucuronide trihydrate and 4MU-2-acetamide-2 deoxy- $\beta$-D-glucoside were obtained from Koch-Light Laboratories Ltd. (Colnbrook, Buckinghamshire, England), 4MU- $\alpha$-D-galactoside from Sigma Chemical Co. (St. Louis, Mo.), and 4MU- $\beta$-D-galactoside from Polysciences, Inc. (Warrington, $\mathrm{Pa}$.). Occasionally, commercial substrate preparations contain excessive amounts of free $4 \mathrm{MU}$, raising the substrate blank value to objectionable levels. This can be removed by extraction of substrate solutions with chloroform followed by brief aeration to remove residual chloroform.

Lactate dehydrogenase was assayed by a modification of Dorfman's procedure (19). Reaction mixture containing $0.05 \mathrm{M}$ sodium pyrophosphate, $\mathrm{pH} 8.8,5.25 \mathrm{mM}$ nicotinamide adenine dinucleotide (NAD) and with or without $7.75 \mathrm{mM}$ lactic acid was prepared and stored frozen. For assay, a $0.4-\mathrm{ml}$ sample of cold dialyzed urine was added to $0.8 \mathrm{ml}$ of thawed reaction mixture in tubes on ice. The mixtures were then incubated at $25^{\circ} \mathrm{C}$ for $30 \mathrm{~min}$ and replaced on ice, and $1.3 \mathrm{ml}$ $\mathrm{Na}_{2} \mathrm{CO}_{3}$ was added to develop fluorescence. Fluorescence of the reduced form of NAD was read immediately on the Aminco fluoro-colorimeter, with interference filters for excitation at $371 \mathrm{nM}$ and emission at $456 \mathrm{nM}$. Blanks of reaction mixture including lactic acid, but water rather than dialyzed urine, were run with each assay and used to correct for fluorescence due to lactic acid. A reaction mixture containing dialyzed urine and NAD, but no lactic acid, was used to correct for fluorescence due to NAD and dialyzed urine. Samples were not assayed in duplicate. However, urine samples reassayed on subsequent days showed this method to be reproducible. Lactate dehydrogenase was expressed as fluorimeter units per hour per milligram creatinine. NAD was obtained from Calbiochem, Inc., San Diego, Calif.

Creatinine was measured with the alkaline picrate method as described by MacFate et al. (20).

\section{RESULTS}

Enzyme assays. Certain complexities arose in establishing the optimal conditions for assay of 
glucuronidase, $\alpha$-galactosidase, $\beta$-galactosidase, and $\beta$-hexosaminidase in urine. Because linear assay conditions are essential for the demonstration of coordinacy, and because the final assay conditions are of general interest, these results are detailed first.

Glucuronidase. The assay of glucuronidase in urine is complicated by the presence of both low $(21-23)$ and high (15) molecular weight inhibitors. While it is a simple matter to remove the low molecular weight inhibitors by dialysis, the high molecular weight inhibitors present more of a problem. Our initial efforts to overcome this were directed at taking advantage of the extreme sensitivity of the fluorescence assay. It was thought that in very dilute enzyme samples the concentration of inhibitor would be too low to measurably affect enzyme activity. However, this was not the case. Fortunately, an alternate solution to the problem was provided by the observations of Sakamoto et al. (15-18). They have defined the structure of the high molecular inhibitors in both urine and tissues as sulfated mucopolysaccharides and have made the important observation that inhibition is reversed by sulfate ion. Fig. 1 presents the apparent glucuronidase activities of dialyzed urine samples obtained from several representative persons as a function of sulfate ion concentration. Inhibition is effectively reversed at concentrations above $0.05 \mathrm{M}$, and we have routinely used $0.1 \mathrm{M}$ for enzyme assay. Inhibition is more pronounced at low substrate concentrations such as the

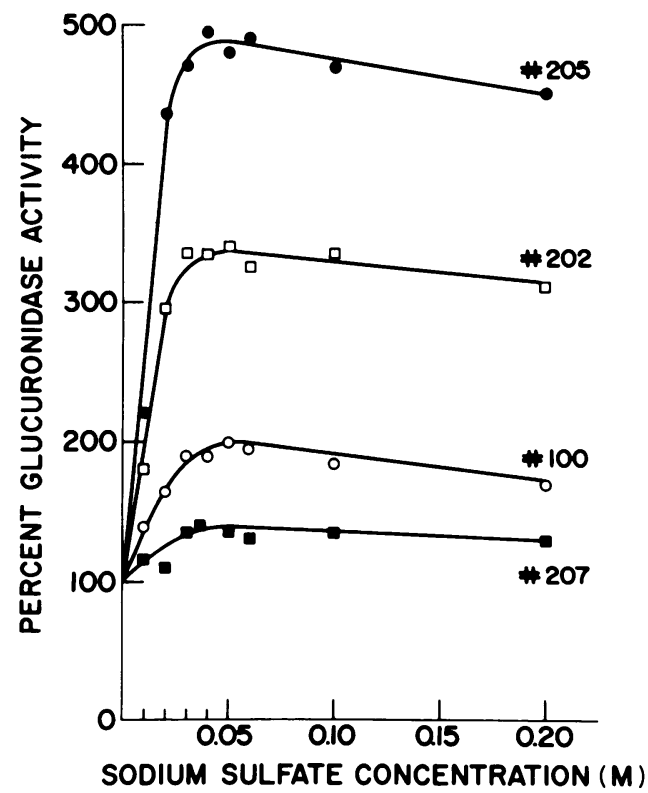

FIGURE 1 Activation of urinary glucuronidase by sulfate ion. Glucuronidase was assayed at increasing concentrations of sodium sulfate in four subjects. The substrate concentration was $0.4 \mathrm{mM}$, which is below the standard concentration used for assay.

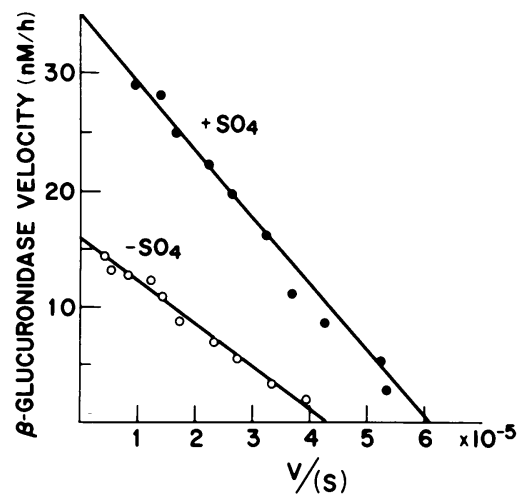

Figure 2 Substrate dependence of $\beta$-glucuronidase in the presence and absence of $0.1 \mathrm{M}$ sulfate. The data are plotted as $V$ versus $V / S$, where the ordinate intercept is $V_{\max }$ and the slope $-K_{m}$.

experiment of Fig. 1. The dependence of enzyme activity on substrate concentration was tested in the presence and absence of $0.1 \mathrm{M}$ sulfate (Fig. 2). These kinetic's of inhibition by the high molecular inhibitor do not fit any of the classic forms of enzyme inhibition, since both $K_{m}$ and $\mathrm{V}_{\max }$ were reduced, but not proportionately. Such an effect would result if the inhibitor binds both to free enzyme molecules and to enzyme-substrate complexes, but more tightly to the enzyme-substrate complex. In the presence of sulfate ion and saturating substrate concentrations, the $\mathrm{pH}$ optimum of the enzyme is 4.6 in acetate buffers (Fig. 3). The use of citrate buffers, which is optimal for the other

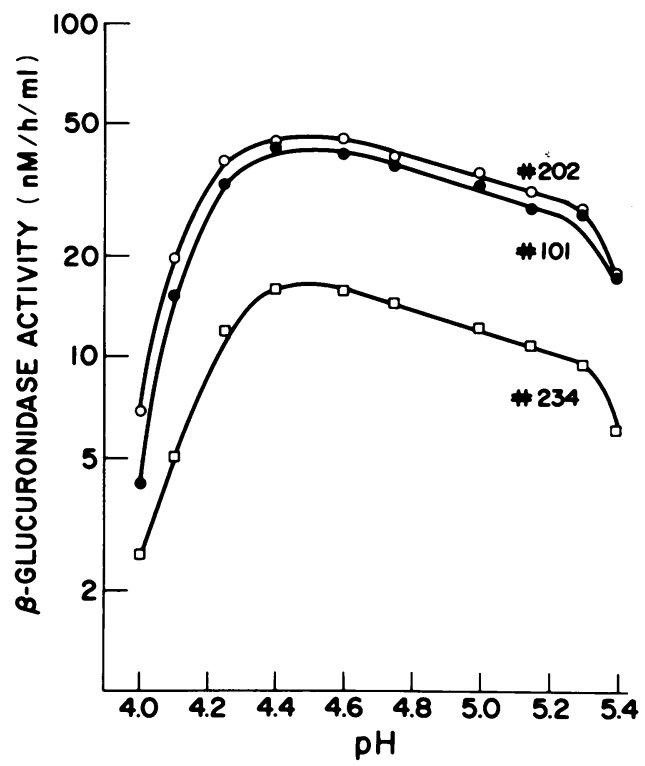

FIgURE 3 pH dependence of $\beta$-glucuronidase activity. Reaction conditions were $3 \mathrm{mM} 4 \mathrm{MU}$-glucuronide, $0.1 \%$ Triton $\mathrm{X}-100,0.1 \mathrm{M} \mathrm{Na}_{2} \mathrm{SO}_{4}$, and $0.1 \mathrm{M}$ acetic acid-sodium acetate mixtures as buffer. Data are plotted on a semilog basis. 


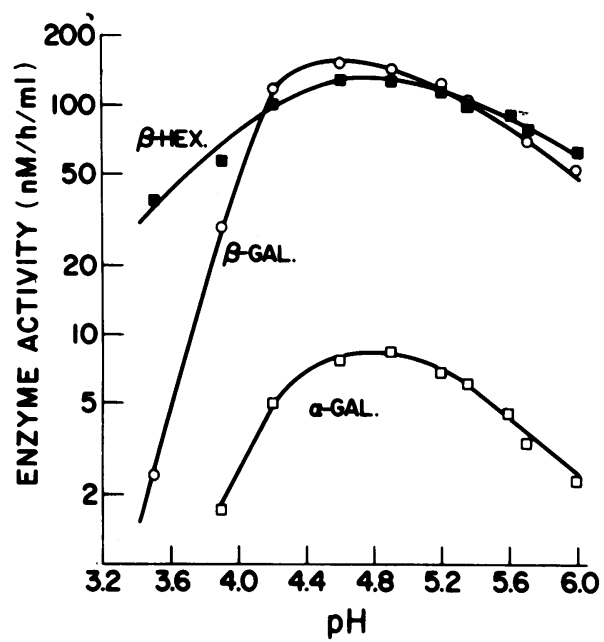

Figure $4 \mathrm{pH}$ dependence of $\alpha$-galactosidase, $\beta$-galactosidase, and $\beta$-hexosaminidase. Reaction conditions are as in Table I, except that $0.1 \mathrm{M}$ citric acid-sodium citrate mixtures were used to adjust $\mathrm{pH}$. Data are plotted on a semilog basis.

enzymes studied here, was avoided, since this substance is an inhibitor of $\beta$-glucuronidase.

Under these assay conditions, namely using dialyzed samples assayed at substrate saturation in the presence of $0.1 \mathrm{M}$ sulfate ion at $\mathrm{pH} 4.6$, the enzyme assay is linear in both enzyme concentration and time. These are the only circumstances under which we have observed linear enzyme assay. In the absence of sulfate ion the reaction is nonlinear, and nonlinearity becomes worse at higher enzyme (urine) concentrations. At the urine concentrations required for assay with colorimetric substrates such as the nitrophenol or phenalphthalein derivatives, the error may be several hundred percent.

The glucuronidase activity present in urine appears to reside in a single species of enzyme molecules. A single activity band was obtained with disc-gel electrophoresis using the modified method of Clarke (24). Dialyzed urine $(10 \mu \mathrm{l})$ was applied to $7 \%$ polyacryl- amide gels, and $300 \mathrm{~V}$ (constant voltage) was applied for $60 \mathrm{~min}$. Glucuronidase activity was visualized in polyacrylamide gels by the method of Hayashi et al. (25), using napthol-AS-BI- $\beta$-D-glucuronide as substrate. Heat inactivation kinetics indicated a single enzyme component with a half-life of $16 \mathrm{~min}$ at $75.5^{\circ}$ in dialysis buffer $(0.03 \mathrm{M}$ citrate buffer, $\mathrm{pH} 6.0$, with $0.1 \mathrm{M} \mathrm{NaCl}$ and $0.1 \%$ Triton).

$\alpha$-Galactosidase and $\beta$-galactosidase. There was no evidence for the presence of inhibitors of either $\alpha$-galactosidase or $\beta$-galactosidase in dialyzed urine samples. The Michaelis constants and $\mathrm{pH}$ optima (Fig. 4) were determined for these two enzymes. For each enzyme, assays were linear in both enzyme concentration and time at the substrate concentration and $\mathrm{pH}$ used. An examination of their heat denaturation kinetics failed to indicate the presence of a second enzyme component for either enzyme.

We should comment that some urine samples behave as though they contain a heat-stable dialyzable factor that inactivates these two enzymes. Similar phenomena have been reported previously (26). The effect results from excess excretion of alkali, raising the urine $\mathrm{pH}$ to the range where these two enzymes are unstable, with enzyme destruction before or during the first hours of dialysis. This results in low and erratic apparent enzyme activities. The effect is very rare in normal individuals, having been observed in only a few percent of our subjects. It is, however, relatively common in certain disease states, such as in patients with cystectomy, where the urine $\mathrm{pH}$ is regularly above 8.0. Under some circumstances it may be advisable to include an appropriate buffer in the collection bottle.

$\beta$-Hexosaminidase. Low molecular weight inhibitors are present in urine, but these are removed by dialysis. The substrate affinity and $\mathrm{pH}$ optimum (Fig. 4) for $\beta$-hexosaminidase were determined. Under optimal conditions of $\mathrm{pH}$ and saturating substrate, the enzyme assay is linear. We suspect the presence of two distinct

TABLE I

Enzyme Properties

\begin{tabular}{|c|c|c|c|c|}
\hline \multirow[b]{3}{*}{ Enzyme } & \multicolumn{2}{|c|}{ Kinetic properties } & \multirow{2}{*}{\multicolumn{2}{|c|}{ Standard reaction conditions }} \\
\hline & & $\mathrm{pH}$ range $(90 \%$ & & \\
\hline & $K m$ & activity level) & Buffer & Substrate \\
\hline & $m M$ & & & \\
\hline$\beta$-Glucuronidase (Gus.) & 0.8 & $4.3-4.7$ & $\begin{array}{l}0.1 \mathrm{M} \text { acetate, } 0.1 \% \text { Triton X-100, } \\
0.1 \mathrm{M} \mathrm{Na}_{2} \mathrm{SO}_{4}, \mathrm{pH} 4.6\end{array}$ & $3 \mathrm{mM} 4 \mathrm{MU}$-glucuronide \\
\hline$\alpha$-Galactosidase ( $\alpha$-Gal.) & 4.5 & $4.5-5.1$ & $0.1 \mathrm{M}$ citrate, $\mathrm{pH} 4.9$ & $7 \mathrm{mM} 4 \mathrm{MU}-\alpha$-D-galactoside \\
\hline$\beta$-Galactosidase ( $\beta$-Gal.) & 0.2 & $4.4-5.1$ & $0.1 \mathrm{M}$ citrate, $0.1 \mathrm{M} \mathrm{NaCl}, \mathrm{pH} 4.9$ & $0.3 \mathrm{mM} 4 \mathrm{MU}-\beta$-D-galactoside \\
\hline$\beta$-Hexosaminase (Hex.) & 0.8 & $4.4-5.2$ & $0.1 \mathrm{M}$ citrate, $0.1 \mathrm{M} \mathrm{NaCl}, \mathrm{pH} 4.9$ & $\begin{array}{l}3 \mathrm{mM} 4 \mathrm{MU} \text {-2-acetamide-2-deoxy- } \\
\beta \text {-D-glucoside }\end{array}$ \\
\hline
\end{tabular}




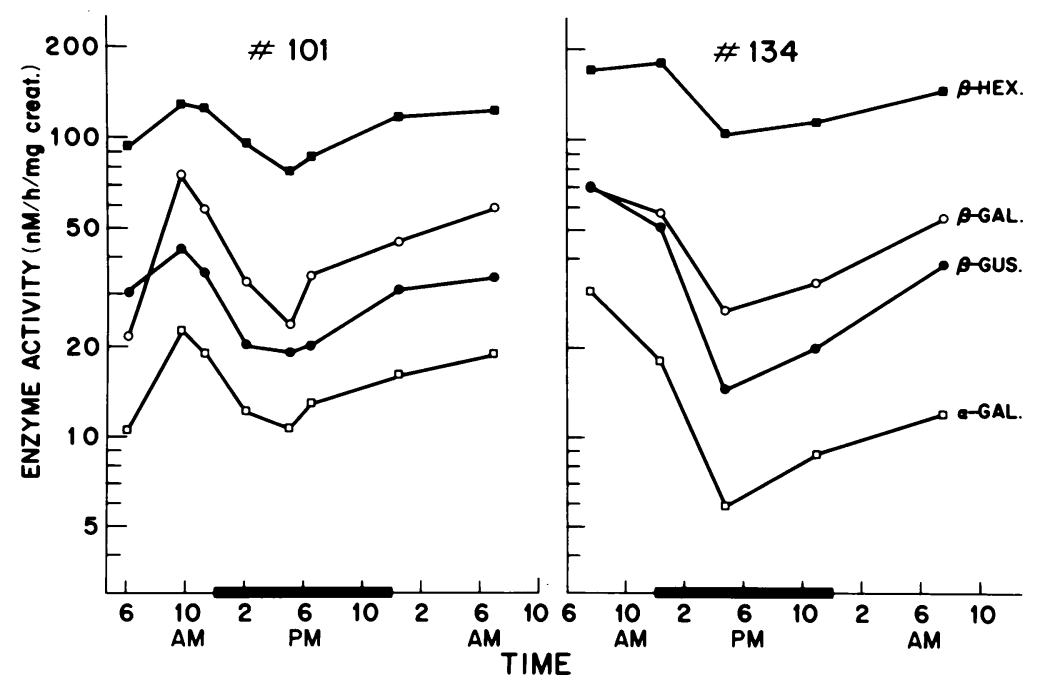

FIGURE 5 Diurnal coordinacy of lysosomal enzymes. Total urine collections over a 24-h period for two subjects. Data are plotted on a semilog basis. Parallel lines imply constant enzyme ratios.

hexosaminidase components in urine, since the heat denaturation kinetics are distinctly biphasic. Dance et al. (27) have reported monophasic denaturation curves; we are unable to explain the difference in results. Hultberg et al. (28) have reported the presence of small amounts of hexosaminidase $B$ in addition to hexosaminidase $\mathrm{A}$ in urine.

Table I summarizes the Michaelis constants, $\mathrm{pH}$ optima, and optimal reaction conditions for these four enzymes. Dance et al. (27) have described reaction conditions for $4 \mathrm{MU}$ substrates of $\beta$-galactosidase and hexosaminidase that differ somewhat from those. In particular, the optimal (i.e., saturating) substrate concentration for hexosaminidase is higher than that suggested by Dance et al. (27). Also, the $\beta$-galactosidase substrate concentration is lower than saturating due to limited solubility of the substrate.

Coordinacy of lysosomal enzymes. The urine content of the four lysosomal enzymes studied, expressed per milligrams of creatinine, varied considerably during a single 24-h cycle and from one day to the next. However, this variation was largely coordinate, in the sense that the activities of all four enzymes fluctuated in a parallel fashion. In Fig. 5 are presented the 24-h cycles of the four enzymes in two subjects. The data are presented as a semi-log plot in which parallel curves indicate a constant ratio of activities. In Fig. 6 are presented the daily fluctuations in enzyme as determined on urine samples voided upon first rising in the morning. It is apparent that the coordinate relationship obtains over extended periods of time, as well as during a single daily cycle.

There is no significant difference in the coordinacy ratios determined by the two methods. For four male subjects the coordinacy ratios for glucuronidase and $\alpha$-galactosidase as determined by first-morning samples were the same as those obtained from daily cycle enzyme samples.

The coordinacy of lysosomal enzymes in urine is a general characteristic of normal individuals. Table II summarizes results for a larger sample of individuals, including both total enzyme activities and the ratios of the other three enzymes to $\alpha$-galactosidase. Coordinacy is reflected in the fact that for each individual the variation in level of each enzyme, expressed as a coefficient of variation, is considerably greater than is the variation in the ratios of one enzyme to another. Similar results have been obtained for a population of

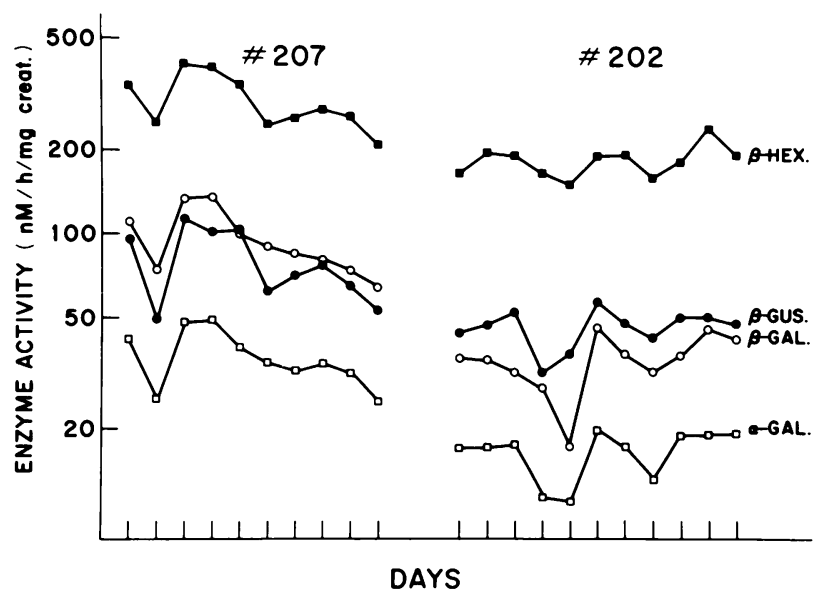

Figure 6 Daily coordinacy of lysosomal enzymes. First morning urines were collected for two subjects and assayed for the four enzyme activities. Data are plotted as in Fig. 5. 
TABLE II

Coordinacy of Lysosomal Enzymes

\begin{tabular}{|c|c|c|c|c|c|c|}
\hline $\begin{array}{l}\text { Subject } \ldots \ldots \ldots \\
\text { No. of samples } \\
\text { Sex } \ldots \ldots \ldots\end{array}$ & $\begin{array}{l}107 \\
(5) \\
\mathrm{M}\end{array}$ & $\begin{array}{l}108 \\
(5) \\
\mathrm{M}\end{array}$ & $\begin{array}{l}116 \\
(5) \\
\mathrm{M}\end{array}$ & $\begin{array}{c}204 \\
(5) \\
\mathrm{F}\end{array}$ & $\begin{array}{c}207 \\
(10) \\
F\end{array}$ & $\begin{array}{c}254 \\
(5) \\
\mathrm{F}\end{array}$ \\
\hline Gus. mean* & 91.1 & 60.7 & 69.7 & 67.0 & 78.7 & 86.1 \\
\hline $\mathrm{CV}$ & 0.15 & 0.14 & 0.12 & 0.30 & 0.29 & 0.38 \\
\hline$\alpha$-Gal. mean & 35.3 & 16.8 & 15.9 & 20.0 & 36.0 & 26.3 \\
\hline $\mathrm{CV}$ & 0.16 & 0.15 & 0.13 & 0.33 & 0.23 & 0.41 \\
\hline$\beta$-Gal. mean & 107 & 60.9 & 69.4 & 53.8 & 94.4 & 98.0 \\
\hline $\mathrm{CV}$ & 0.20 & 0.13 & 0.16 & 0.34 & 0.26 & 0.40 \\
\hline Hex. mean & 373 & 204 & 137 & 321 & 299 & 319 \\
\hline $\mathrm{CV}$ & 0.14 & 0.19 & 0.13 & 0.24 & 0.22 & 0.32 \\
\hline Gus./ $\alpha-G a l$. & 2.59 & 3.61 & 4.39 & 3.36 & 2.17 & 3.32 \\
\hline $\mathrm{CV}$ & 0.02 & 0.06 & 0.02 & 0.13 & 0.11 & 0.06 \\
\hline$\beta$-Gal./ $\alpha-\mathrm{Gal}$ & 3.01 & 3.63 & 4.35 & 2.70 & 2.62 & 3.75 \\
\hline $\mathrm{CV}$ & 0.08 & 0.05 & 0.05 & 0.20 & 0.07 & 0.09 \\
\hline Hex./ $\alpha-$ Gal. & 10.6 & 12.1 & 8.63 & 11.8 & 8.36 & 12.5 \\
\hline $\mathrm{CV}$ & 0.08 & 0.13 & 0.03 & 0.13 & 0.08 & 0.09 \\
\hline
\end{tabular}

Successive morning samples obtained on six subjects were assayed under standard conditions. Means and coefficients of variation (CV) (standard deviation/mean) were calculated for enzyme units per milligram of creatinine.

* Abbreviations: Gus. $=\beta$-glucuronidase; $\alpha$-Gal. $=\alpha$-galactosidase; $\beta$-Gal.

$=\beta$-galactosidase $;$ Hex. $=\beta$-hexosaminidase .

TABLE III

Constancy of Enzyme Excretion over Time

\begin{tabular}{|c|c|c|c|c|c|c|}
\hline \multirow[b]{2}{*}{ Subject } & \multirow{2}{*}{\multicolumn{2}{|c|}{ Year/month }} & \multirow[b]{2}{*}{$N$} & \multicolumn{3}{|c|}{ Enzyme excretion (mean $\pm \mathrm{SE}$ ) } \\
\hline & & & & $\alpha$-Gal.* & Gus. & Gus. $/ \alpha$-Gal. \\
\hline \multirow[t]{7}{*}{200} & 1975 & April & (5) & $22.4 \pm 6.1$ & $55.5 \pm 6.1$ & $2.50 \pm 0.10$ \\
\hline & & May & (5) & $14.6 \pm 2.2$ & $40.4 \pm 5.9$ & $2.80 \pm 0.13$ \\
\hline & & June & (5) & $12.3 \pm 1.9$ & $32.3 \pm 5.2$ & $2.60 \pm 0.07$ \\
\hline & & August & (5) & $17.6 \pm 1.1$ & $47.8 \pm 3.3$ & $2.72 \pm 0.06$ \\
\hline & & September & (5) & $16.3 \pm 2.6$ & $50.0 \pm 6.5$ & $3.15 \pm 0.19$ \\
\hline & 1976 & March & (5) & $13.3 \pm 1.4$ & $39.0 \pm 3.5$ & $2.96 \pm 0.11$ \\
\hline & & May & (5) & $15.9 \pm 1.5$ & $43.7 \pm 4.3$ & $2.74 \pm 0.10$ \\
\hline Average (means) & & & - & 16.1 & 44.1 & 2.78 \\
\hline \multirow[t]{7}{*}{202} & 1975 & March & (11) & $16.4 \pm 1.0$ & $45.7 \pm 2.1$ & $2.83 \pm 0.09$ \\
\hline & & April & $(5)$ & $19.5 \pm 1.8$ & $56.6 \pm 4.3$ & $2.93 \pm 0.11$ \\
\hline & & May & (5) & $14.1 \pm 1.7$ & $49.1 \pm 5.1$ & $3.56 \pm 0.22$ \\
\hline & & June & (5) & $15.7 \pm 2.0$ & $47.2 \pm 6.4$ & $3.01 \pm 0.06$ \\
\hline & & August & (5) & $15.8 \pm 3.7$ & $46.6 \pm 11.2$ & $2.95 \pm 0.20$ \\
\hline & 1976 & March & (5) & $17.2 \pm 2.6$ & $55.5 \pm 16.3$ & $3.05 \pm 0.37$ \\
\hline & & May & (5) & $13.2 \pm 1.1$ & $35.8 \pm 2.4$ & $2.77 \pm 0.25$ \\
\hline Average (means) & & & - & 16.0 & 48.1 & 3.01 \\
\hline
\end{tabular}

First-morning samples were obtained on successive days at various times over a period of $14 \mathrm{mo}$. The data presented are for $\alpha$-galactosidase and $\beta$-glucuronidase; similar results were obtained for $\beta$-galactosidase and $\beta$-hexosaminidase. Enzyme excretion is calculated as units per milligram of creatinine.

* See footnote to Table II for abbreviations. 
TABLE IV

Enzyme Excretion Rates in a Human Population

\begin{tabular}{|c|c|c|c|c|c|c|c|}
\hline \multirow[b]{2}{*}{ Number sampled } & \multirow{2}{*}{$\begin{array}{c}\text { Total adult } \\
\text { population* } \\
125\end{array}$} & \multicolumn{4}{|c|}{ Ages, $(\mathbf{y r})$} & \multicolumn{2}{|c|}{ Sex* } \\
\hline & & $\begin{array}{c}4-14 \\
15\end{array}$ & $\begin{array}{c}15-20 \\
38\end{array}$ & $\begin{array}{c}21-45 \\
47\end{array}$ & $\begin{array}{l}46^{+} \\
40\end{array}$ & $\begin{array}{l}M \\
55\end{array}$ & $\begin{array}{l}F \\
70\end{array}$ \\
\hline & \multicolumn{7}{|c|}{ U/mg creatinine } \\
\hline $\begin{array}{l}\text { Glu. } \$ \text { Mean } \\
\text { SD }\end{array}$ & $\begin{array}{l}57.3 \\
24.1\end{array}$ & $\begin{array}{l}81.9 \\
43.6\end{array}$ & $\begin{array}{l}54.0 \\
21.0\end{array}$ & $\begin{array}{l}53.0 \\
19.3\end{array}$ & $\begin{array}{l}65.4 \\
29.8\end{array}$ & $\begin{array}{l}56.7 \\
18.7\end{array}$ & $\begin{array}{l}57.8 \\
27.8\end{array}$ \\
\hline $\begin{array}{l}\alpha \text {-Gal. Mean } \\
\text { SD }\end{array}$ & $\begin{array}{l}19.7 \\
8.29\end{array}$ & $\begin{array}{l}21.1 \\
8.51\end{array}$ & $\begin{array}{r}16.6 \\
5.06\end{array}$ & $\begin{array}{c}19.6 \\
9.60\end{array}$ & $\begin{array}{l}22.6 \\
8.22\end{array}$ & $\begin{array}{l}19.7 \\
8.70\end{array}$ & $\begin{array}{c}19.6 \\
8.01\end{array}$ \\
\hline $\begin{array}{l}\beta \text {-Gal. Mean } \\
\text { SD }\end{array}$ & $\begin{array}{l}59.6 \\
32.3\end{array}$ & $\begin{array}{l}83.1 \\
48.1\end{array}$ & $\begin{array}{l}51.3 \\
23.3\end{array}$ & $\begin{array}{l}53.5 \\
25.2\end{array}$ & $\begin{array}{l}74.2 \\
41.2\end{array}$ & $\begin{array}{l}61.8 \\
25.0\end{array}$ & $\begin{array}{l}57.8 \\
37.2\end{array}$ \\
\hline $\begin{array}{l}\beta \text {-Hex. Mean } \\
\quad \text { SD }\end{array}$ & $\begin{array}{r}192 \\
95.9\end{array}$ & $\begin{array}{r}197 \\
76.4\end{array}$ & $\begin{array}{c}133 \\
41.7\end{array}$ & $\begin{array}{l}181 \\
66.6\end{array}$ & $\begin{array}{l}259 \\
118\end{array}$ & $\begin{array}{c}187 \\
89.6\end{array}$ & $\begin{array}{l}195 \\
101\end{array}$ \\
\hline
\end{tabular}

Average enzyme excretion by age and sex for a population of randomly selected, ostensibly healthy, persons. The data calculated are from five successive morning samples on each person. Standard deviations (rather than standard errors) are given to indicate the extent of population diversity.

* Excludes age 4-14 yr.

f See footnote to Table II for abbreviations.

over a hundred normal persons. Enzyme levels and coordinacy ratios do not change significantly over extended periods of time (Table III), nor do they vary in any systematic way during the menstrual cycle of adult females.

Population distribution. From these results it is apparent that for each acid hydrolase an individual is characterized by two parameters. The first is the total enzyme excretion, the average of which can be determined with some accuracy if sufficient measurements are made; and the second is the coordinacy ratio of that enzyme to other acid hydrolases, which can be determined with considerable accuracy since it is quite constant. The distribution of both parameters has been measured in a population of 125 normal individuals, with $\alpha$-galactosidase as the reference enzyme for expressing coordinacy ratios.

The daily excretion of each enzyme varies widely in the normal adult population (Table IV). This is not sex related. The lack of sexual dimorphism is noteworthy, since such a dimorphism is seen in mice (29) and rats (30) for glucuronidase. There is a tendency for prepubertal children to show somewhat higher excretion rates (about $50 \%$ higher). In addition, there is a tendency to slightly higher enzyme excretion in older persons; this is most pronounced for hexosaminidase. When plotted as cumulative probabilities, the enzyme distributions are log normal (Fig. 7), indicating that a number of factors influence total excretion and that each factor has a proportional, or relative, effect on enzyme excretion.

As expected, the range of coordinacy ratios is less, approximating four- to fivefold (Table V). There are no significant changes in coordinacy ratios with sex or age, again with the possible exception of an increasing excretion of hexosaminidase in older people. Like total enzyme excretion, coordinacy ratios are log normal distributions (Fig. 8).

Origins of coordinacy. The four lysosomal enzymes

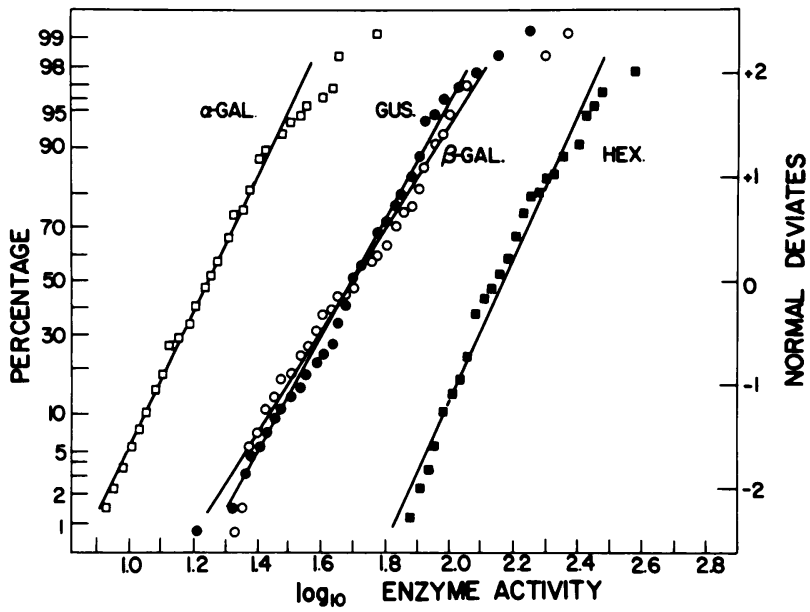

FIGURE 7 Log-normal population distributions for total enzyme excretion. Cumulative population frequencies (using a linear scale of normal deviates) are plotted against the log of enzyme activity. The data points do not represent each individual subject, which would be much too crowded, but instead the accumulated frequency reached at the end of each class interval. A straight line over the 5-95\% range indicates that for the great majority of the population, log enzyme activity is normally distributed. The data for hexosaminidase are for the age range $15-45 \mathrm{yr}$; for the other three enzymes it is for $15+\mathrm{yr}$ and includes the $56+$ age group. 
TABLE V

Enzyme Coordinacy Ratios

\begin{tabular}{|c|c|c|c|c|c|c|c|}
\hline \multirow[b]{2}{*}{ Number sampled } & \multirow{2}{*}{$\begin{array}{c}\text { Total adult } \\
\text { population* } \\
125\end{array}$} & \multicolumn{4}{|c|}{ Ages $(\mathbf{y r})$} & \multicolumn{2}{|c|}{ Sex* } \\
\hline & & $\begin{array}{c}4-14 \\
15\end{array}$ & $\begin{array}{c}15-20 \\
38\end{array}$ & $\begin{array}{c}21-45 \\
47\end{array}$ & $\begin{array}{l}46^{+} \\
40\end{array}$ & $\begin{array}{l}\mathrm{M} \\
55\end{array}$ & $\begin{array}{l}F \\
70\end{array}$ \\
\hline Glu./ $\alpha$-Gal. $\ddagger$ Mean & 3.04 & 3.89 & 3.29 & 2.93 & 2.95 & 3.10 & 3.01 \\
\hline SD & 0.88 & 0.90 & 0.89 & 0.85 & 0.84 & 0.91 & 0.84 \\
\hline$\beta$-Gal./ $\alpha$-Gal. Mean & 3.03 & 4.22 & 3.02 & 2.86 & 3.22 & 3.17 & 2.88 \\
\hline SD & 0.93 & 2.34 & 0.81 & 1.07 & 0.86 & 0.98 & 0.88 \\
\hline Hex./ $\alpha$-Gal. Mean & 10.2 & 10.4 & 8.3 & 10.2 & 12.0 & 10.1 & 10.3 \\
\hline SD & 3.9 & 3.9 & 1.7 & 3.4 & 5.0 & 4.1 & 3.5 \\
\hline
\end{tabular}

Enzyme coordinacy ratios calculated for the same population as Table IV.

* Excludes age 4-14 yr.

\$ See footnote to Table II for abbrevations.

studied are large, ranging in molecular weight from 110,000 to over 300,000 , suggesting that their presence in urine does not result from glomerular filtration of serum enzymes. To confirm this, we have tested whether the amount of enzyme excreted per unit volume of blood filtered (i.e., enzyme units per milligram creatinine in urine) depends upon the concentration of enzyme in blood. Serum and urine levels did not fluctuate in parallel, and we failed to find any relationship between the two (Fig. 9). Similar results were obtained on a total of five subjects.

If the lysosomal enzymes enter urine after the glomerulus, this could result from active secretion of the enzymes or from the shedding of entire cells, or their contents, into urine. To help distinguish these two possibilities, we have used lactate dehydrogenase as a nonlysosomal marker enzyme. Measurements of this enzyme over 24-h cycles, or on repeated morning samples, failed to show coordinacy with the lysosomal enzyme (Table VI). While there is a very high correlation coefficient between the excretion of other acid hydrolases and $\alpha$-galactosidase, there is only a weak correlation between the excretion of lactate dehydrogenase and $\alpha$-galactosidase. This is the expected result if exfoliated cells are not the source of urinary acid hydrolases.

Enzyme correlations. The existence of coordinacy suggests the existence of a common physiological

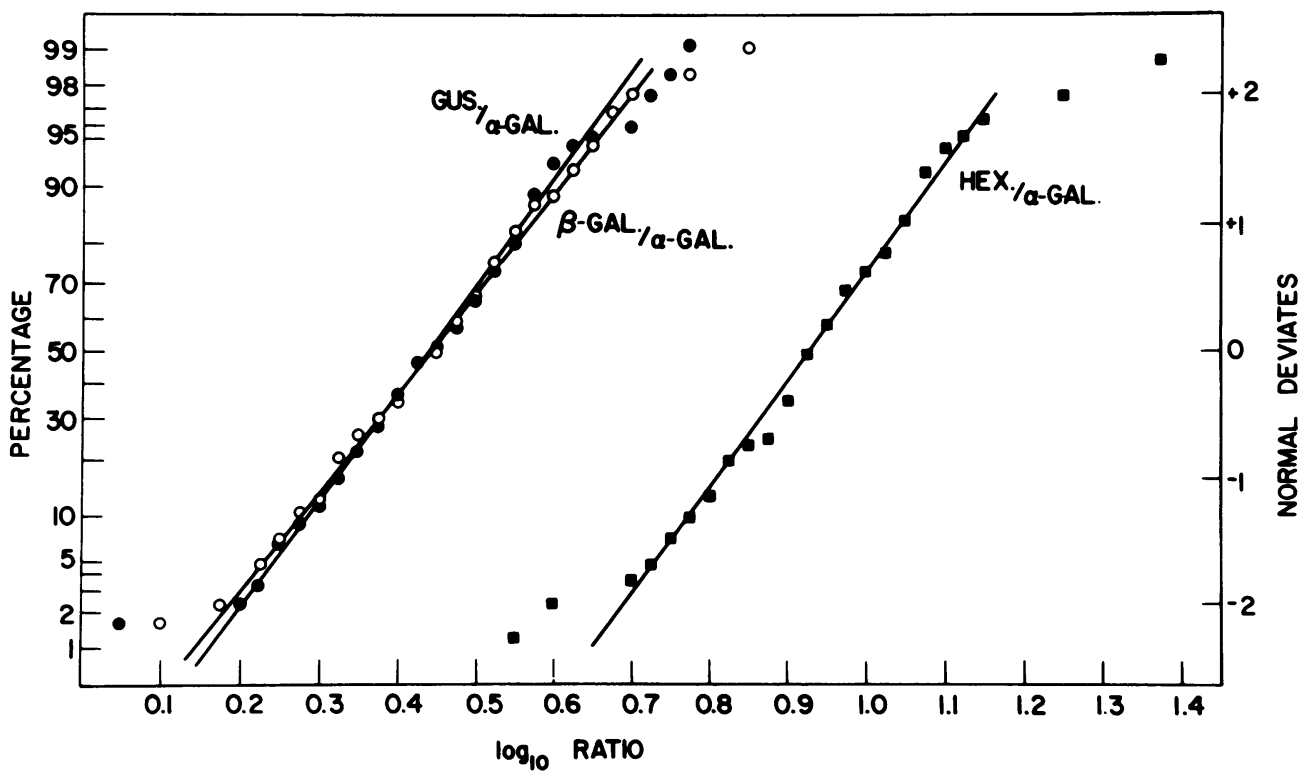

FIGURE 8 Log-normal population distributions for enzyme coordinacy ratios. Cumulative population frequencies are plotted against the log of enzyme activity as in Fig. 7. 


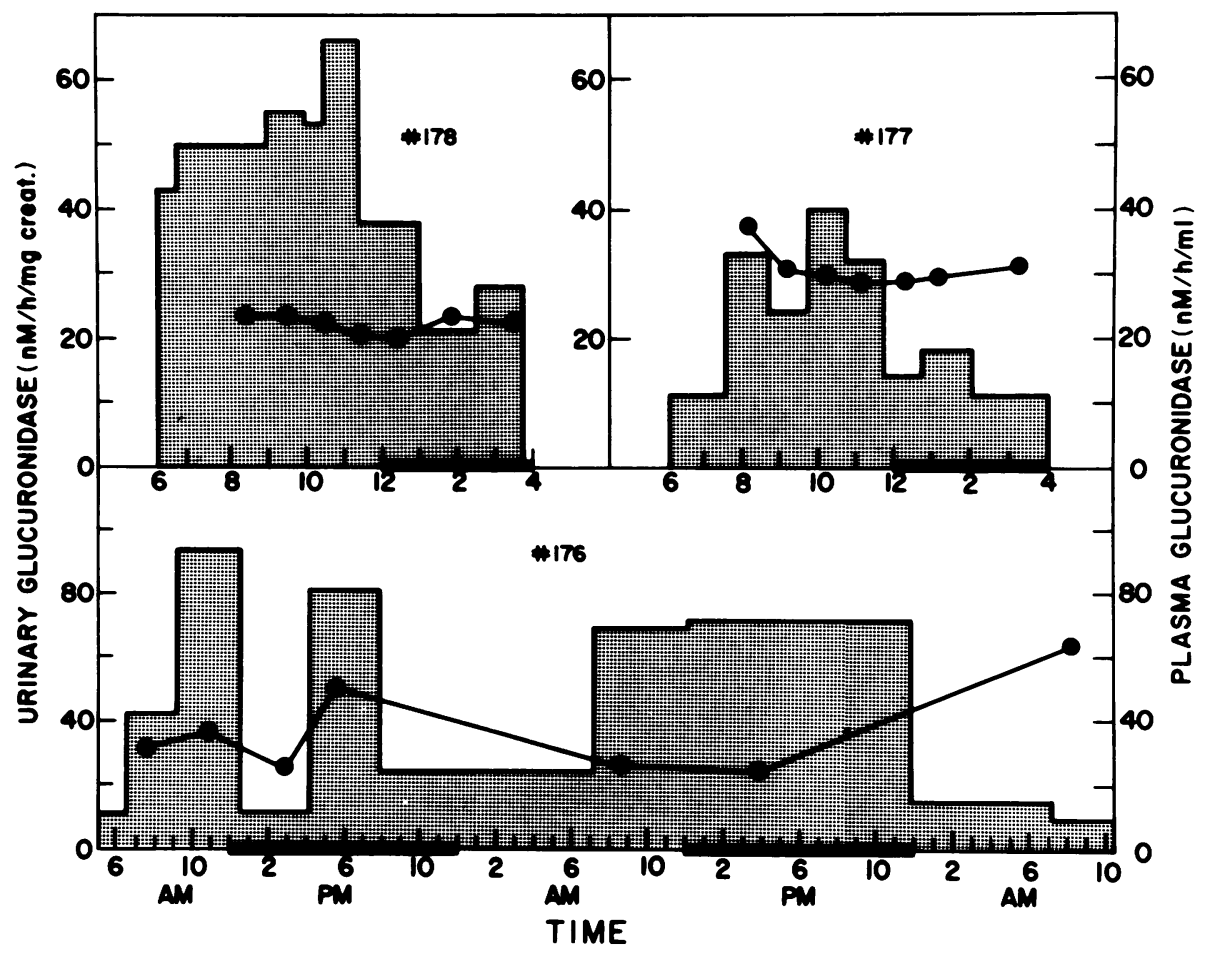

FIGURE 9 Lack of coordinacy between plasma and urinary $\beta$-glucuronidase. Total urine collections and blood samples obtained periodically. Urinary glucuronidase levels (shaded area) are plotted as horizontal lines over the time interval of each collection; plasma enzyme levels $(\mathrm{O}-\mathrm{O})$ are plotted at the time each sample was obtained.

pathway for the excretion of all four hydrolases. Given the data so far presented, a likely possibility for this pathway is extrusion of lysosomes from epithelial cells (see Discussion). We can estimate how much of the population variation is in this common pathway (which affects all four enzymes simultaneously), and how much is in the entry of individual enzymes into this pathway, by determining the extent to which enzyme excretion levels are correlated between individuals (Table VII). From the average correlation coefficient of all measurements $\left(r_{\text {ave }}=0.715\right)$, we estimate that half of the population variability is in the common pathway

TABLE VI

Lack of Coordinacy between LDH and $\alpha$-Galactosidase

\begin{tabular}{lccccc}
\hline & & \multicolumn{4}{c}{ Subject } \\
\cline { 2 - 6 } & & 100 & 101 & 104 & 134 \\
\multicolumn{1}{c}{ Parameter } & $n=8$ & $n=8$ & $n=6$ & $n=5$ \\
\hline$\alpha$-Gal.* & Mean \pm SD & $12.6 \pm 3.6$ & $15.4 \pm 4.5$ & $11.2 \pm 2.2$ & $15.0 \pm 9.6$ \\
Gus./ $\alpha$-gal. & Mean \pm SD & $2.42 \pm 0.53$ & $1.93 \pm 0.41$ & $2.15 \pm 0.22$ & $2.49 \pm 0.24$ \\
$r$ & & 0.88 & 0.86 & 0.99 & 0.98 \\
LDH $\$ / \alpha$-gal. Mean \pm SD & $4.92 \pm 1.46$ & $2.40 \pm 0.99$ & $11.0 \pm 4.0$ & $2.34 \pm 0.94$ \\
$r$ & 0.24 & 0.01 & 0.23 & 0.64 \\
\hline
\end{tabular}

Coordinacy ratios for $\mathrm{LDH}$ and $\beta$-glucuronidase relative to $\alpha$-galactosidase for successive morning samples on four subjects. Standard deviations are given to indicate the range of sample values over which the correlation coefficient $(r)$ was calculated.

* See footnote to Table II for abbreviations.

\$ LDH, lactate dehydrogenase. 
TABLE VII

Population Correlations for Hydrolase Excretion Levels

\begin{tabular}{lcccc}
\hline & Gus. $^{*}$ & $\alpha$-Gal. & $\beta$-Gal. & Hex. \\
\hline Gus. & - & 0.681 & 0.849 & 0.679 \\
$\alpha$-Gal. & & - & 0.732 & 0.573 \\
$\beta$-Gal. & & & - & 0.778 \\
Hex. & & & & - \\
\hline
\end{tabular}

Correlation coefficients $(r)$ are given for total excretion levels (units per milligram of creatinine) between each pair of enzymes for the normal population of 125 persons aged $15+$ years studied. All three adult groups are included for each enzyme.

* See footnote to Table II for abbreviations.

$\left(r^{2}=0.51\right)$ and half in the individual enzymes ( $1-$ $\left.r^{2}=0.49\right)$.

\section{DISCUSSION}

Coordinacy. The lysosomal enzymes present in human urine undergo coordinate variation. The absolute levels of each enzyme fluctuate around a mean in such a manner that the ratio of one enzyme to another is constant. This observation does not apply to all urinary enzymes, since it is not shared by lactate dehydrogenase, and it does not reflect variations in the water content of the urine, since the data are expressed per milligram of creatinine. The enzyme excretion pattern of normal individuals is quite constant over extended periods of time, with respect to both absolute amounts of enzyme and coordinacy ratios. The patterns are not sex dependent. Among adults they are not age dependent, except for a tendency towards higher hexosaminidase in older persons. Prepubertal children have somewhat elevated levels of excretion of all acid hydrolases tested, by about $50 \%$. Before attempting to consider the significance of these results, it is necessary to make some comments on the problem of enzyme assay.

Assay. The fluorogenic 4MU substrates used here for the assay of acid hydrolases are far more sensitive, on the order of a hundredfold or more, than the more traditional $p$-nitrophenol and phenolphthalein substrates. This permits the assay of much more dilute urine samples, which, combined with prior dialysis of the urine, provides for simple, uncomplicated, linear assays of the two galactosidases and hexosaminidase. The case of $\beta$-glucuronidase is more difficult, however, because of the presence of high molecular weight mucopolysaccharide inhibitors that are active even in very dilute and dialyzed enzyme samples. Fortunately, the inclusion of sulfate ion in the reaction mixture reverses these inhibitions. Taking advantage of this, it has been possible to devise linear assay conditions for $\beta$-glucuronidase as well. It should be noted that nearly all of the published literature on urinary levels of glucuronidase has ignored the problem of the high molecular weight inhibitors, and their action is included in conventional assay procedures. This effect is particularly serious at higher enzyme (urine) concentrations, such as those required using the less sensitive $p$-nitrophenol or phenolphthalein substrates. Therefore, caution is required in interpreting literature reports of changes in apparent glucuronidase activity in human urine. Older procedures underestimate glucuronidase levels to an unknown extent, and it is not clear, when differences in enzyme activity were observed, whether these represented changes in the enzyme itself or changes in levels of inhibitor excretion. We find that levels of sulfate-reversible inhibitor are sensitive to a variety of environmental factors, including diet.

Origins of coordinacy. The existence of coordinacy suggests that the lysosomal enzymes are excreted as a package. The number of packages released per hour fluctuates during the day and from one day to the next; but the average enzyme composition of packages is quite constant. Some information is available regarding the probable source of these packages. The high molecular weights of the enzymes and the failure to observe any relationship between serum and urine enzyme levels suggest that they do not represent enzyme derived by glomerular filtration. Similar observations failing to correlate levels of serum and urine acid hydrolases have been reported by Begum (9) and Erickson et al. (31). If the acid hydrolases enter the urine subsequent to filtration, then two possibilities present themselves. The packages could represent the enzyme content of exfoliated cells, or they could represent the end result of active secretion into the urinary tract. That the enzymes are probably not derived from exfoliated cells is suggested by the failure to observe coordinacy with lactate dehydrogenase, a nonlysosomal enzyme that one would expect to be coordinate if the packages represented the contents of an entire cell. The notion that urinary lysosomal enzymes are actively secreted agrees with similar observations in experimental animals where epithelial cells appear to extrude their contents into the tubular lumen. In mice the lysosomal enzyme content of kidney proximal tubule epithelial cells can be extensively modulated by both hormonal and genetic manipulations (32-34). The kidney content of these enzymes is directly related to the rate at which epithelial cells synthesize these enzymes (33) and inversely related to the ease of release (34). Electron micrographs of actively secreting animals show the presence of secretion material in epithelial cell lysosomes clustered about the brush border (35).

Population variation. There is considerable varia- 
tion between individuals both as to the average number of packages excreted per day and the composition of the packages, the total excretion of a given enzyme by an individual representing the product of these two parameters. From the fact that population distributions for both total enzyme excretion and coordinacy ratios are $\log$ normal, we conclude that a number of physiological factors, each acting in a proportional manner, influence both parameters. From measurements of the extent to which enzyme excretion levels are correlated between individuals, we estimate that population variation in each parameter contributes nearly equally to the total population variation in excretion of a single enzyme. Experiments that we shall report separately indicate that variation in both parameters is primarily genetic in origin.

Animal experiments provide some indication as to the nature of genetic variation that can affect lysosomal enzyme excretion. At the level of individual lysosomal enzymes, in addition to genetic polymorphism affecting the primary structure of enzyme molecules (36-39) and the attachment of glycosyl side chains (40), there is population variation in regulatory genes controlling enzyme concentration. Regulatory genes have been reported that control enzyme levels in the whole organism $(41,42)$ and in specific tissues $(41,43,44)$, as well as determine the ability to induce enzyme synthesis in response to hormonal stimuli (33). In the human population, genetic variation in genes such as these would affect the supply of one or another lysosomal enzyme in kidney, resulting in individual differences in coordinacy ratios.

In addition to these genes, which affect single lysosomal enzymes, a set of genes has been identified in mice that affects lysosomal enzymes collectively by determining rates of lysosome secretion $(45,46)$. Variation in this latter group affects the number of packages released per hour and the excretion of all lysosomal enzymes. If human lysosomal enzyme excretion procedes by a similar route, then the equivalent genes in the human population would affect overall rates of enzyme excretion, but not coordinacy ratios. Interestingly, all the genes of this type so far discovered in mice also affect pigmentation, presumably as a result of abnormal melanosome transport, melanosomes being structurally related to lysosomes. The most intensively studied mouse mutant, beige, is a rather exact animal equivalent of the human genetic defect Chediak-Higashi syndrome. Children affected with this disease are characterized by hypopigmentation, increased susceptibility to disease, and the presence of abnormally large lysosomes in many cell types (47).

The degree of correlation among the general human population in the excretion of each enzyme studied (Table VII) suggests that about one-half the population variation affects individual enzymes, and hénce coordinacy ratios, and about one-half affects the collective excretion process, and hence overall rates of excretion but not coordinacy ratios. To the extent that this variation is genetic in origin, we might expect a similar partition of polymorphic genes; perhaps one-half of the genetic variation occurring in our population sample is in genes determining the synthesis of individual enzymes and one-half is in genes determining the excretion process.

Physiologic function. In the absence of additional physiological information, we can only speculate on the possible function of extruding lysosomes, or their contents, into the lumen of the urinary tract. Two hypotheses offer themselves for further test. The first is that the process represents a bacteriostatic or bacteriocidal device to prevent pathogen infection in the bladder and urinary tract. Urine is typically acid in its $\mathrm{pH}$ and provides a favorable environment for the action of lysosomal enzymes. Arguing against this possibility is the relative resistance of living bacterial cells to digestion by lysosomal enzymes, particularly as dilute as they are in urine, and the necessity that host cells lining the urinary tract would require mechanisms to defend themselves against the action of lysosomal enzymes. The second hypothesis is that extrusion of lysosomal contents is primarily an excretion mechanism operating in proximal tubule epithelial cells, its most probable purpose being the elimination of indigestible residues left after hydrolysis of high molecular weight materials recaptured from the glomerular filtrate.

\section{ACKNOWLEDGMENTS}

This work was supported by grants from the National Institutes of Health (GM-19521) and The Tobacco Research Council (1080).

\section{REFERENCES}

1. Tappel, A. L., 1969. Lysosomal enzymes and other components. In Lysosomes in Biology and Pathology. J. T. Dingle and H. B. Fell, editors. North Holland Publishing Co., Amsterdam. 2: 209-213.

2. Wakabayashi, M. 1970. $\beta$-Glucuronidase in metabolic hydrolysis. In Metabolic Conjugation and Metabolic Hydrolysis. W. H. Fishman, editor. Academic Press, Inc., New York. 2: 519-602.

3. Bank, N., and S. H. Bailine. 1965. Urinary $\beta$-glucuronidase activity in patients with urinary tract infection. N. Engl.J. Med. 272: 70-75.

4. Roberts, A. P., J. Frampton, S. M. M. Karim, B. Pharm, and R. W. Beard. 1967. Estimation of $\beta$-glucuronidase activity in urinary-tract infection. N. Engl.J. Med. 276: 1468-1470.

5. Ronald, A. R., F. Silverblatt, H. Clark, R. E. Cutler, and M. Turck. 1971 . Failure of urinary $\beta$-glucuronidase activity to localize the site of urinary tract infection. Appl. Microbiol. 21: 990-9992.

6. Kallet, H. A., and L. Lapco. 1967. Urine $\beta$-glucuronidase activity in urinary tract disease. J. Urol. 97: 352-356. 
7. Gonick, H. C., H. J. Kramer, and A. E. Schapiro. 1973. Urinary $\beta$-glucuronidase in renal disease. Arch. Intern. Med. 132: 63-69.

8. Schapiro, A., W. Paul, and H. Gonick. 1968. Urinary $\beta$-glucuronidase in urologic diseases of the kidneys. $J$. Urol. 100: 146-157.

9. Begum, A. 1973. Urinary excretion of $\beta$-glucuronidase in protein-calorie malnutrition. Clin. Chim. Acta. 46: 229234.

10. Plum, C. M. 1967. $\beta$-Glucuronidase activity in serum, cerebrospinal fluid and urine in normal subjects and in neurological and mental patients. Enzymol. Biol. Clin. 8: 97-112.

11. Hradec, E., R. Petrik, and J. Pezlarova. 1965. The activity of $\beta$-glucuronidase in cases of bladder neoplasms.J. Urol. 94: $430-435$.

12. Boyland, E., J. E. Gasson, and D. C. Williams. 1957. Enzyme activity in relation to cancer. Br.J. Cancer. 11: $120-129$.

13. Boyland, E., D. M. Wallace, and D. C. Williams. 1955. The activity of the enzymes sulphatase and $\beta$-glucuronidase in the urine, serum and bladder tissue. Br. J. Cancer. 9: $62-79$.

14. Kerr, W. K., M. Barkin, J. D'Aloisio, and Z. Menczyk. 1963. Biochemical factors in the etiology of carcinoma of the bladder. Cancer. 16: 633-638.

15. Sakamoto, W., and O. Nishikaze. 1972. Purification of $\beta$-glucuronidase and its inhibitors from pregnancy urine. Enzyme. 13: 211-223.

16. Sakamoto, W., O. Nishikaze, and E. Sakakibara. 1973. Isolation of an inhibitor of $\beta$-glucuronidase from porcine sublingual gland. Biochim. Biophys. Acta. 329: 72-80.

17. Sakamoto, W., O. Nishikaze, and E. Sakakibara. 1974. Isolation of two inhibitors of $\beta$-glucuronidase from porcine sublingual and submaxillary glands. Biochim. Biophys. Acta. 343: 409-415.

18. Sakamoto, W., O. Nishikaze, and E. Sakakibara. 1974. Isolation of an inhibitor of $\beta$-glucuronidase from human saliva. J. Biochem. (Tokyo). 75: 675-677.

19. Dorfman, L. E., E. Amador, and W. E. C. Wacker. 1963. Urinary lactic dehydrogenase activity. J.A.M.A. (J. Am. Med. Assoc.). 184: 123-128.

20. MacFate, R. P., C. Cohn, L. Eichelberger, and J. Cooper. 1954. Symposium on Azotemia. Am. J. Clin. Pathol. 24: $511-571$

21. Abul-Fadl, M. A. M. 1957. Inhibition and activation of $\beta$-glucuronidase in urine. Biochem. J. 65: 16P-17P.

22. Paul, W., A. Schapiro, and H. Gonick. 1967. Studies of human kidney and urine $\beta$-glucuronidase. I. Biochemical characteristics. Enzymol. Biol. Clin. 8: 47-66.

23. Kushinsky, S., and V. L. Chen. 1967. Urinary inhibitors of $\beta$-glucuronidase. Enzymol. Biol. Clin. 8: 266-282.

24. Clarke, J. T. 1964. Simplified "disc" (polyacrylamide gel) electrophoresis. Ann. N. Y. Acad. Sci. 121: 428-436.

25. Hayashi, M., U. Nakajima, and W. H. Fishman. 1964. The cytologic demonstration of $\beta$-glucuronidase employing napthol AS-BI glucuronide and hexazonium pararosanilin; a preliminary report. J. Histochem. Cytochem. 12: 293-297.

26. Thomas, G. H. 1969. $\beta$-D-Galactosidase in human urine: deficiency in generalized gangliosidosis. J. Lab. Clin. Med. 74: 725-731.

27. Dance, N., R. G. Price, D. Robinson, and J. L. Stirling. 1969. $\beta$-Galactosidase, $\beta$-glucosidase and $N$-acetyl- $\beta$ glucosaminidase in human kidney. Clin. Chim. Acta. 24: 189-197.
28. Hultberg, B., N. Norden, and P. A. Ockerman, 1972. Urinary excretion of acid hydrolases in disease. Scand.J. Clin. Lab. Invest. 30: 215-219.

29. Patterson, J. F., M. Cheney, and W. H. Fishman. 1964. Preputial gland $\beta$-glucuronidase response to testosterone and to two anabolic steroids. Endocrinology. 75: 273276.

30. Fishman, W. H. 1951. $\beta$-Glucuronidase and the action of steroid hormones. Ann. N. Y. Acad. Sci. 54: 548-557.

31. Erickson, R. P., R. Sandman, and C. J. Epstein. 1975. Lack of relationship between blood and urine levels of glycosaminoglycans and lysosomal enzymes. Biochem. Med. 12: 331-339.

32. Fishman, W. H. 1965. The influence of steroids on $\beta$-glucuronidase in mouse kidneys. In Methods in Hormone Research. R. I. Dorfman, editor. Academic Press, Inc., New York. 4B: 273-326.

33. Swank, R. T., K. Paigen, and R. E. Ganschow. 1973. Genetic control of glucuronidase induction in mice. $J$. Mol. Biol. 81: 225-243.

34. Brandt, E. J., and R. T. Swank. 1976. The Chediak-Higashi (Beige) mutation in two mouse strains. Am. J. Pathol. 82: 573-586.

35. Paigen, K., R. T. Swank, S. Tomino, and R. E. Ganschow. 1975. The molecular genetics of mammalian glucuronidase. J. Cell. Physiol. 85: 379-392.

36. Paigen, K. 1961. The effect of mutation upon the intracellular location of $\beta$-glucuronidase. Exp. Cell Res. 25: 286-301.

37. Lalley, P. A., and T. B. Shows. 1974. Lysosomal and microsomal glucuronidase: genetic variant alters electrophoretic mobility of both hydrolases. Science (Wash. D. C.). 185: $442-444$.

38. Breen, G. A. M., A. J. Lusis, and K. Paigen. 1977. Linkage of genetic determinants for mouse $\alpha$-galactosidase electrophoresis and activity. Genetics. 85: 73-84.

39. Lusis, A. J., and J. D. West. 1976. X-linked inheritance of a structural gene for $\alpha$-galactosidase in Mus musculus. Biochem. Genet. 14: 849-855.

40. Dizik, M., and R. W. Elliott. 1977. A gene apparently determining the extent of sialylation of lysosomal $\alpha$-mannosidase in mouse liver. Biochem. Genet. 15: $31-46$.

41. Paigen, K. 1961. The genetic control of enzyme activity during differentiation. Proc. Natl. Acad. Sci. U. S. A. 47: 1641-1649.

42. Felton, J., M. Meisler, and K. Paigen. 1974. A locus determining $\beta$-galactosidase activity in the mouse. J. Biol. Chem. 249: 3267-3272.

43. Lusis, A. J., and K. Paigen. 1975. Genetic determination of the $\alpha$-galactosidase developmental program in mice. Cell. 6: $371-378$.

44. Paigen, K., M. Meisler, J. Felton, and V. Chapman. 1976. Genetic determination of the $\beta$-galactosidase developmental program in mouse liver. Cell. 9: 533-539.

45. Brandt, E. J., R. W. Elliott, and R. T. Swank. 1975. Defective lysosomal enzyme secretion in kidneys of Chediak-Higashi (Beige) mice. J. Cell Biol. 67: 774788 .

46. Novak, E. K., and R. T. Swank. 1977. Altered lysosomal enzyme levels in mouse pigment mutants. Fed. Proc. 36: 859 .

47. Root, R. K., A. S. Rosenthal, and D. J. Balestra. 1972. Abnormal bactericidal, metabolic, and lysosomal functions of Chediak-Higashi syndrome leukocytes. J. Clin. Invest. 51: 649-665. 